\title{
Magnetometric Evaluation of the Effects of Man-Made Mineral Fibers on the Function of Macrophages Using the Macrophage Cell Line RAW 264.7
}

\author{
Kaori SHIBATA ${ }^{1 *}$, Yuichiro KUDO ${ }^{1}$, Masashi TSUNODA ${ }^{1}$, Mayuko HOSOKAWA ${ }^{1}$, \\ Yasuhiro SAKAI ${ }^{2}$, Makoto KOTANI ${ }^{3}$ and Yoshiharu AIZAWA ${ }^{1}$ \\ ${ }^{1}$ Department of Preventive Medicine and Public Health, Kitasato University School of Medicine, 1-15-1 Kitasato, \\ Sagamihara-shi, Kanagawa 228-8555, Japan \\ ${ }^{2}$ Department of Anatomy, Kitasato University School of Medicine, Kanagawa, Japan \\ ${ }^{3}$ Department of Electronic Engineering, Tokyo Denki University, Tokyo, Japan
}

Received October 26, 2006 and accepted January 15, 2007

\begin{abstract}
The toxic effects of man-made mineral fibers (MMMFs) have been evaluated by cell magnetometry using alveolar macrophages (AMs). Recently, on the other hand, the murine macrophage cell line, RAW 264.7, became available and has been used as an in vitro model of AMs. The objective of this study was to determine whether or not cell magnetometry using RAW 264.7 cells can be used to evaluate the toxic effects of MMMFs. RAW 264.7 cells were exposed to one of the MMMFs, potassium octatitanate (PT) or silicon carbide whisker $(\mathrm{SiC})$ at $0,20,40$ and $60 \mu \mathrm{g} / \mathrm{ml}$, or chrysotile as a positive control at $0,15,20$ and $25 \mu \mathrm{g} / \mathrm{ml}$. The toxic effects of fibers were evaluated by cell magnetometry and LDH assay. For this comparison, AMs were also exposed to chrysotile fibers (CF). In the RAW 264.7 cells exposed to PT 20, 40, 60 or SiC 20, 40, 60, CF 15, 20 and $25 \mu \mathrm{g} / \mathrm{ml}$, significant delayed relaxation were observed compared with the respective control. In the LDH assay, significant increases in LDH in the supernatant of the cells exposed to PT 20, 40, 60, SiC 20, 40, 60 and $C F$ 15, 20, $25 \mu \mathrm{g} / \mathrm{ml}$ were observed. In AMs exposed to CF $20,25 \mu \mathrm{g} / \mathrm{ml}$ significant delayed relaxation and significant increases in LDH compared with the control were observed. The levels of MMMFs that induced significant differences were similar for cell magnetometry and LDH. The levels of CF that induced significant differences in cell magnetometry and LDH were identical for RAW 264.7 cells and AMs. Our results suggest that cell magnetometry using RAW 264.7 cells is adequate to evaluate the cytotoxicity of exposure to MMMFs.
\end{abstract}

Key words: Magnetometry, Cytoskeleton, Cell line, Man-Made Mineral Fibers, Cytotoxicity

\section{Introduction}

Man-made mineral fibers (MMMFs) have been developed as substitutes for asbestos, since the associations between exposure to asbestos and diseases such as pulmonary cancer and malignant mesothelioma have been reported ${ }^{1,2)}$. MMMFs are considered safer than asbestos, based on their physical and chemical characteristics ${ }^{3,4}$. However, Stanton et al..$^{5)}$

*To whom correspondence should be addressed. have suggested that not only asbestos but also any long and thin fibers that are retained in the lung for a long time, could cause lung injury, fibrosis and lung cancer. The current evaluations of toxic effects of MMMFs are insufficient. Therefore, safety evaluations of MMMFs are urgently needed.

MMMFs are taken into the body by inhalation and phagocytosed by alveolar macrophages (AMs $)^{6}$. In previous studies, AMs obtained from rats have been used for assessments of $\mathrm{MMMFs}^{7,8)}$. A unique method called cell magnetometry for the evaluation of toxic effects of fibrous 
materials on the functions of AMs was developed in 1996 ${ }^{9}$. It provided useful information for the toxic effects of MMMFs, such as silicon carbide whiskers ${ }^{10)}(\mathrm{SiC})$, potassium octatitanate whiskers $^{11)}(\mathrm{PT})$, rock wool ${ }^{12)}$ and micro glass fibers ${ }^{13)}$, as described in previous studies.

Rats must be sacrificed to obtain AMs for the cell magnetometry. The number of AMs obtained from each rat is limited to several millions, therefore, many animals are needed to evaluate each substance. Recently the murine macrophage cell line RAW 264.7 became available and has been used as an in vitro model of $\mathrm{AMs}^{14-16)}$. Cell magnetometry using RAW 264.7 cells may be useful.

The purpose of this study is whether or not RAW 264.7 cells can be used in the evaluation of toxic effects of MMMFs by cell magnetometry. PT and $\mathrm{SiC}$, which have a high toxicity on AMs among other MMMFs ${ }^{10,11}$, were chosen as representative MMMFs. RAW 264.7 cells were exposed to PT, $\mathrm{SiC}$ or chrysotile fiber $(\mathrm{CF})$, which is one of the toxic asbestos fibers, as a positive control. The toxic effects of fibers were evaluated by cell magnetometry and LDH in the supernatant of the cells. LDH level is the index of cell membrane damage and cell death. Electron microscopic observations were used to confirm that RAW 264.7 cells engulfed fibers. The observation by the fluorescent antibody method $^{13)}$ was used to check the change in cytoskeleton. For the comparison, AMs were also exposed to $\mathrm{CF}$ and the toxic effects were evaluated by cell magnetometry and LDH assay.

\section{Materials and Methods}

\section{Materials}

PT and SiC were supplied by the Japan Fibrous Materials Research Association (JFM) (Tokyo). Chrysotile fibers (CF) were supplied by the Japan Association for the Working Environment Measurement (Tokyo). In Fig. 1a-c, the SEM image of CF, PT and SiC fibers is shown, respectively. The geometric mean of the length (geometric SD) and that of the width (geometric SD) of CF was $2.60(2.30) \mu \mathrm{m}$ and $0.15(1.80) \mu \mathrm{m}$, respectively. The geometric mean of the length (geometric SD) and that of the width (geometric SD) of PT was $6.00(2.04) \mu \mathrm{m}$ and 0.35 (1.51) $\mu \mathrm{m}$, respectively. The geometric mean of the length (geometric SD) and that of the width (geometric SD) of $\mathrm{SiC}$ was $6.40(2.45) \mu \mathrm{m}$ and $0.30(1.58) \mu \mathrm{m}$, respectively, according to the study of Kohyama et al. ${ }^{17)}$. The composition of PT was Ti $84.73 \%$, $\mathrm{Nb} 0.23 \%$, $\mathrm{Zr} 0.03 \%$, and $\mathrm{K} 15.01 \%$; that of $\mathrm{SiC}$ was $\mathrm{SiC}$ $99.6 \%$ and $\mathrm{Al}_{2} \mathrm{O}_{3} 0.16 \%$; and that of $\mathrm{CF}$ was $\mathrm{Mg} 56.88 \%, \mathrm{Si}$ $39.98 \%$ and $\mathrm{Fe} 3.14 \%$. These materials were suspended in phosphate buffered saline (PBS), pH7.4, sterilized by autoclaving at $121^{\circ} \mathrm{C}$ for $20 \mathrm{~min}$

\section{Cell line}

A murine peritoneal macrophage cell line RAW 264.7 was obtained from Dainippon Sumitomo Pharma Co., Tokyo. The cells were cultured at $37^{\circ} \mathrm{C}$ with $5 \% \mathrm{CO}_{2}$ in Dulbecco's modified Eagle's medium (DMEM, ICN Biomedicals, Inc., Aurora, $\mathrm{OH})$.

\section{Preparation of alveolar macrophage}

Male F344 rats were obtained from CLEA Japan Inc. (Tokyo). Each rat was anesthetized and bled to death by incising the abdominal aorta. Bronchoalveolar lavage was performed by instilling $4 \mathrm{ml}$ cold PBS, $\mathrm{pH} 7.4$, containing $0.1 \%$ EDTA (ethylenediaminetetraacetic acid) through a tracheal catheter, followed by gentle aspiration. This procedure was repeated 9 times. Six rats were used for each experiment. Fluid from each lavage contained AMs and was pooled and centrifuged at $650 \times \mathrm{g}$ for $10 \mathrm{~min}$. The AMs pellet was suspended in serum free medium (MacrophageSFM liquid, Life Technologies, Inc., Rockville, MD, USA).

\section{Cell culture}

The viabilities of RAW264.7 or AMs used were $90 \%$ or more determined by the trypan-blue exclusion test. Cells were counted with hematocytometer and RAW 264.7 cells were adjusted to $25 \times 10^{4}$ cells $/ \mathrm{ml}$ and AMs were adjusted to $10^{6}$ cells $/ \mathrm{ml}$. The cell number set from preliminary experiment. Each cell population was seeded into glass tube (Shibata Scientific Technology, Ltd., Tokyo). The base of the glass tube was $2.5 \mathrm{~cm}^{2}$.

\section{Cell magnetometry}

Cell magnetometric measurement was performed by a method previously reported by Keira et al. ${ }^{9)}$. The diameter of $\mathrm{Fe}_{3} \mathrm{O}_{4}$ ranged from 0.08 to $0.57 \mu \mathrm{m}$, and the geometrical mean diameter of $\mathrm{Fe}_{3} \mathrm{O}_{4}$ was $0.26 \mu \mathrm{m}$. The cells were exposed to particles of $\mathrm{Fe}_{3} \mathrm{O}_{4}$ (Toda Kogyo Co., Hiroshima) suspended in PBS at the concentration of $50 \mu \mathrm{g} / \mathrm{ml}$ added to each glass tube containing cells. One hour after exposure to $\mathrm{Fe}_{3} \mathrm{O}_{4}$, the cells were exposed to each tested material.

RAW 264.7 cells were exposed to CF $0,15,20$ or $25 \mu \mathrm{g} /$ $\mathrm{ml}, \mathrm{PT}$ or $\mathrm{SiC} 20,40$ or $60 \mu \mathrm{g} / \mathrm{ml}$ and incubated in a humidified incubator with $5 \% \mathrm{CO}_{2}$ at $37^{\circ} \mathrm{C}$ for $48 \mathrm{~h}$. AMs exposed to $\mathrm{CF} 0,15,20,25 \mu \mathrm{g} / \mathrm{ml}$ and after the exposure incubated in a humidified incubator with $5 \% \mathrm{CO}_{2}$ at $37^{\circ} \mathrm{C}$ for $18 \mathrm{~h}$. The incubation times were set from our preliminary experiments. There were 6 tubes for each concentration of tested glass tubes. After the incubation, the cells in the glass tubes were 
a

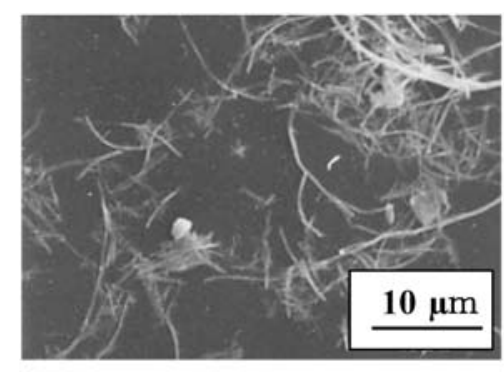

$\mathrm{b}$

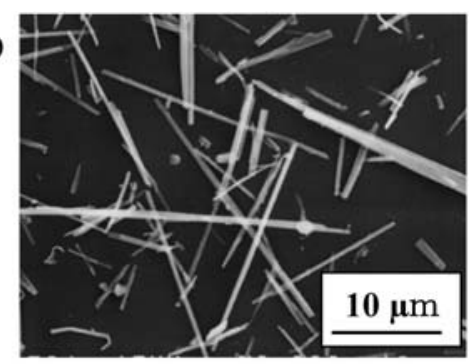

$\mathrm{c}$

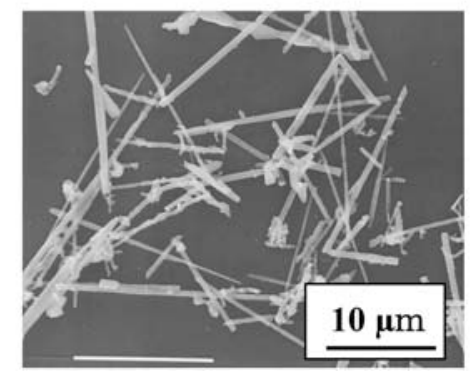

Fig. 1. The SEM image of asbestos fiber (CF) and MMMFs (PT, SiC).

a. Chrysotile fibers (CF), b. potassium octatitanate whisker (PT), and c. silicon carbide whisker (SiC), respectively. PT image from Watanabe et al. ${ }^{11)}$.

magnetized by a magnetizer at $70 \mathrm{mT}$ for $10 \mathrm{~ms}$ using the magnetizer of a cell magnetometry apparatus. Immediately after magnetization, the remnant magnetic field (RMF) was measured for 20 min with a fluxgate magnetometer and recorded with a pen recorder. The glass tubes were set on the sample plate. The strength of magnetic field was measured every $6 \mathrm{~s}$. The temperature was maintained at $37^{\circ} \mathrm{C}$ by an air fan with a thermostat under a magnetic shield.

The RMF over 20 min after the magnetization was plotted. The rapid reduction of the RMF after the termination of magnetization is called relaxation. The relaxation at $20 \mathrm{~min}$ after magnetization, $\mathrm{B}_{20}(\%)$, was obtained from the formula $\mathrm{B}_{20}(\%) 100 / \mathrm{B}_{0}$, where $\mathrm{B}_{20}$ is RMF 20 min after the termination of magnetization. The logarithm of RMF for the first 2 min after magnetization was calculated to obtain the intercept with the $y$-axis. The decay constant $(\lambda)$ was obtained from the formula $\mathrm{B}=\mathrm{B}_{0} \mathrm{e}^{-\lambda t}$, where $\mathrm{B}_{0}$ is the intercept with the $\mathrm{y}$ axis, and $B$ is RMF at $t$ seconds after the termination of external magnetization.

\section{Lactate dehydrogenase assay}

For the lactate dehydrogenase assay (LDH) measurement, the RAW 264.7 cells and AMs were exposed to tested material as described above. After the exposure, the supernatant was sampled and centrifuged at 1,400 rpm for $5 \mathrm{~min}$. After centrifugation, the concentration of LDH in the supernatant was determined by CytoTox96 Non-Radioactive Cytotoxicity Assay (Promega Corp., Madison, WI). The absorbance at $492 \mathrm{~nm}$ was measured by using a microplate-reader (MPRA4, Tosho Corp., Tokyo). LDH level in each sample was expressed as a percentage of the PBS-added group.

\section{Morphological observation}

The RAW 264.7 cells, adhered to a poly-L-lysine-coated glass disc in a glass tube, were exposed to PBS $50 \mu \mathrm{l}, \mathrm{CF}$ 20, $\mathrm{PT}$ or $\mathrm{SiC} 60 \mu \mathrm{g} / \mathrm{ml}$ and followed by incubation with $5 \% \mathrm{CO}_{2}$ at $37^{\circ} \mathrm{C}$ for $48 \mathrm{~h}$ as described above.

For the FITC method ${ }^{13)}$, the cultured cells were fixed with acetone for $10 \mathrm{~min}$. After washing and blocking, cells were stained for 90 min with $\alpha$-tubulin FITC conjugate (SigmaAldrich, Tokyo) by the direct antibody method. The each samples was dehydrated with 50\% ethanol, and mounted in glycerol. The cells were examined by immunofluorescence micrography (Axioplan 2, Zeiss Co., Oberkochen, Germany).

For electron microscopic observation, cells were treated as follows ${ }^{13)}$. The samples were exposed to PBS $50 \mu \mathrm{l}, \mathrm{CF}$ $20 \mu \mathrm{g} / \mathrm{ml}$, PT or SiC $60 \mu \mathrm{g} / \mathrm{ml}$, and incubated with $5 \% \mathrm{CO}_{2}$ at $37^{\circ} \mathrm{C}$ for $48 \mathrm{~h}$. After the incubation, the cells were allowed to adhere to polycationic-treated glass slides by pipetting. The adherent cells were washed with $0.1 \mathrm{M}$ cacodylate buffer (pH7.4) and prefixed with $1 \%$ glutaraldehyde at $4{ }^{\circ} \mathrm{C}$ for 3 h. They were washed again with $0.1 \mathrm{M}$ cacodylate buffer 


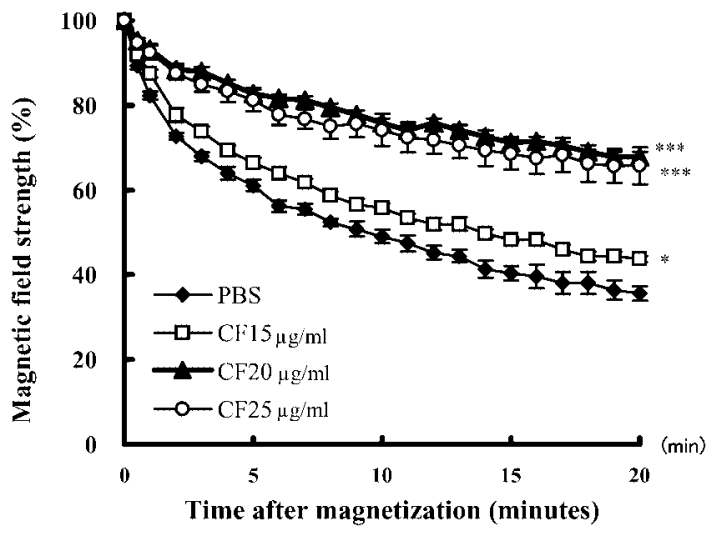

a RAW 264.7

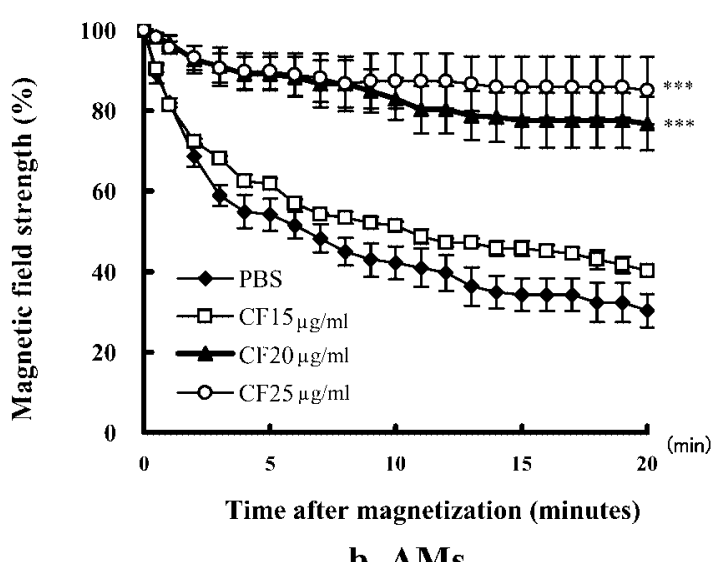

b AMs

Fig. 2. The relaxation curve of RAW 264.7 cells and alveolar macrophage (AM) exposed to CF after magnetization. a. RAW 264.7 cells. b. AMs. The remnant magnetic field strength (RMF) was expressed as a percentage of the initial RMF value. The mean RMF over 20 min after magnetization was plotted. Bars represent SE. Mean values of the $\mathrm{B}_{20}(\%)$ were compared among the groups $(* p<0.05$, $* * * p<0.001$; compared with the PBS groups).

(pH7.4) fixed with $1 \%$ osmium tetroxide at $4{ }^{\circ} \mathrm{C}$ for $3 \mathrm{~h}$. Each sample was subsequently re-washed with $0.1 \mathrm{M}$ cacodylate buffer ( $\mathrm{pH} 7.4)$ for observation with a transmission electron microscope (TEM). The fixed cells were subjected to a process of dehydration, resin embedding, ultrathin sectioning with an ultramicrotome and electron staining with uranyl acetate and lead citrate. TEM observation of the cells was performed using a Hitachi H-600 (Hitachi Ltd., Tokyo). For observation with a scanning electron microscope (SEM), the cells were subjected to a process of conductive staining, dehydration, drying and conductive treatment. SEM observation of the cells was performed using a Hitachi S4500FE (Hitachi Ltd., Tokyo).

\section{Statistical analysis}

Data are shown as mean $\pm \mathrm{SE}$ of the results obtained from six experiments conducted for both the control and experimental groups. The statistical significance of differences among the groups was examined by one-way ANOVA (analysis of variance) using StatView 5.0 (SAS, Cary, CA), and Fisher's PLSD (protected least significant difference) test was used as a post hoc test (significance level: $p<0.05$ ).

\section{Results}

The relaxation curves are shown for RAW 264.7 cells and AMs exposed to $\mathrm{CF}$ in Fig. 2a, $2 \mathrm{~b}$ respectively. In the RAW 264.7 cells, the mean values of $\mathrm{B}_{20}(\%)$ in the CF 15 , 20 and $25 \mu \mathrm{g} / \mathrm{ml}$ groups were significantly higher compared to that in the PBS groups. In the AMs, the mean values of $\mathrm{B}_{20}(\%)$ in the $20,25 \mu \mathrm{g} / \mathrm{ml}$ groups were significantly higher compared to those in the PBS groups. The mean values of decay constant are given for RAW 264.7 cells and AMs exposed to CF in Fig. 3a, 3b respectively. The mean decay constants of RAW 264.7 cells exposed to 15,20 and $25 \mu \mathrm{g} /$ $\mathrm{ml}$ of CF were significantly lower compared to those of the respective PBS groups. The mean value decay constants of AMs exposed to 20 and $25 \mu \mathrm{g} / \mathrm{ml}$ of CF were significantly lower compared to those of the PBS groups.

The relaxation curves are shown for RAW 264.7 cells exposed to PT and $\mathrm{SiC}$ in Fig. 4a, 4b, respectively. In the PT groups, RAW 264.7 cells exposed to 20, 40 and $60 \mu \mathrm{g} /$ $\mathrm{ml}$ the mean values of $\mathrm{B}_{20}(\%)$ were significantly higher compared to those of the respective PBS groups. In the $\mathrm{SiC}$ groups, RAW 264.7 cells exposed to 20,40 and $60 \mu \mathrm{g} / \mathrm{ml}$ groups, the mean values of $\mathrm{B}_{20}(\%)$ were significantly higher compared to those in the respective PBS groups. The extent of the delay in relaxation occurs dose-dependently for PT and SiC. The mean values of decay constants are given for RAW 264.7 cells exposed to PT and SiC in Fig. 5a, b, respectively. In the $\mathrm{PT}$ groups, the mean decay constants of the groups exposed to 20, 40 and $60 \mu \mathrm{g} / \mathrm{ml}$ were significantly lower compared to those of the respective PBS groups. In the $\mathrm{SiC}$ groups, the mean decay constants of the groups exposed to 20,40 and $60 \mu \mathrm{g} / \mathrm{ml}$ were significantly lower compared to those of the respective PBS groups. For both groups exposed to $\mathrm{SiC}$ and PT, the decay constants of the groups became smaller as the concentrations increased. 


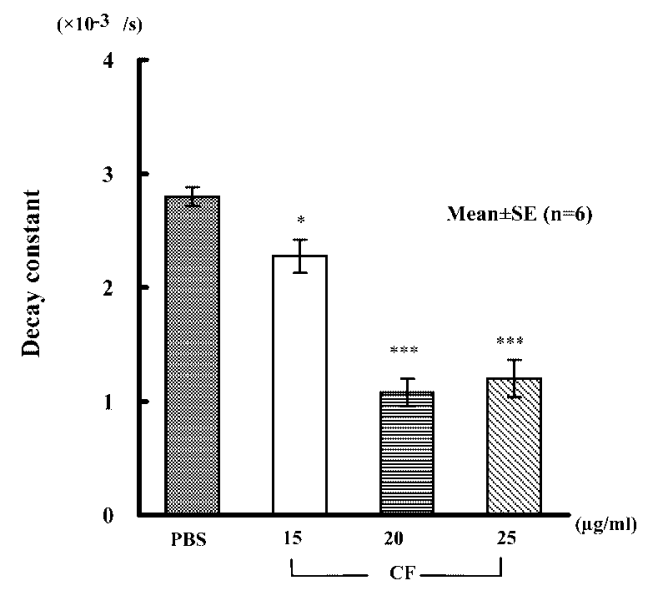

a RAW 264.7

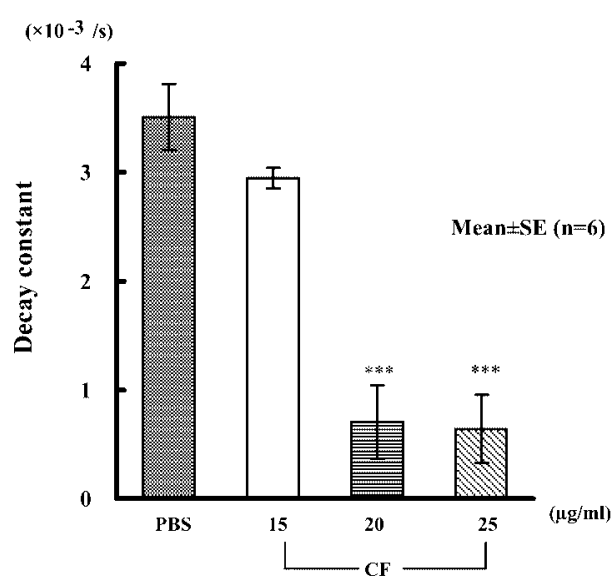

b AMs

Fig. 3. The decay constant of RAW 264.7 cells and alveolar macrophage (AM) exposed to CF after magnetization.

a. RAW 264.7cells. b. AMs. Bars represent mean values, and error bars represent SE $(n=6)$. The mean values of decay constants $(\lambda)$ were compared among the groups $(* p<0.05$, $* * * p<0.001$; compared with the PBS groups).

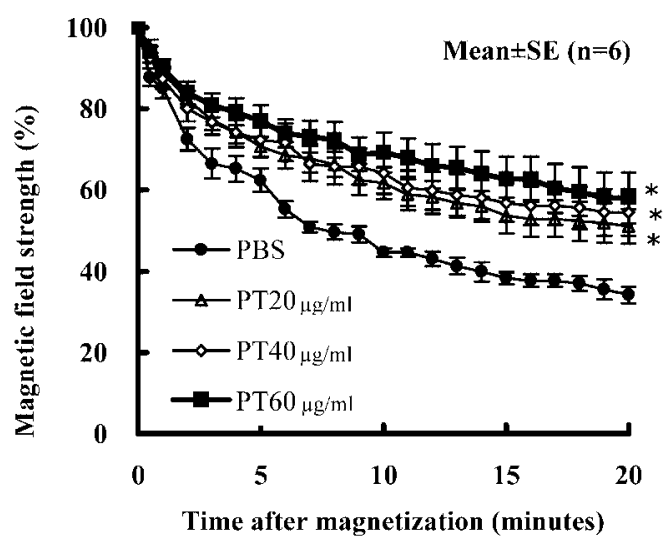

a PT

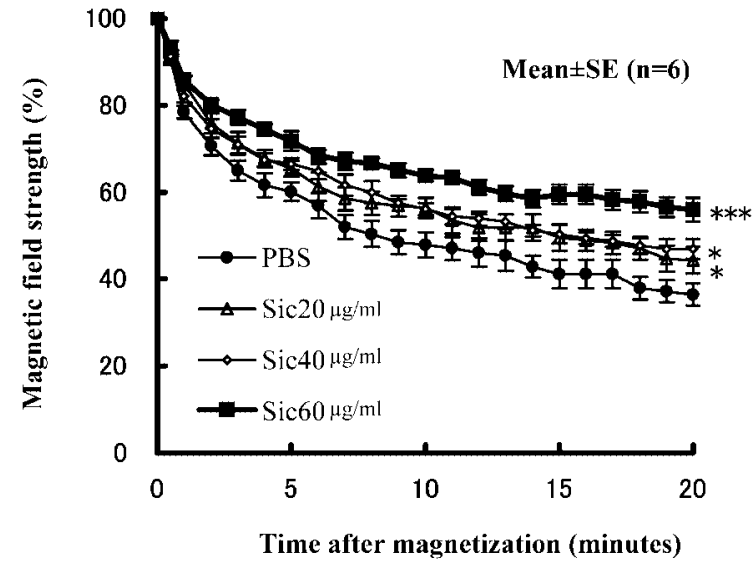

b $\mathrm{SiC}$

Fig. 4. The relaxation curve of $\mathrm{RAW} 264.7$ cells exposed to $\mathrm{PT}$ or $\mathrm{SiC}$ after magnetization.

The remnant magnetic field strength (RMF) was expressed as a percentage of the initial RMF value. The mean RMF over 20 min after magnetization was plotted. Bars represent SE. Mean values of the $\mathrm{B}_{20}(\%)$ were compared among the groups $\left({ }^{*} p<0.05\right.$, $* * * p<0.001$; compared with the PBS groups).

\section{LDH assay}

The mean concentration of LDH in the supernatant of RAW 264.7 cells exposed to CF is shown in Fig. 6a, while that of AMs is shown in Fig. 6b. RAW 264.7 cells exposed to CF 15,20 and $25 \mu \mathrm{g} / \mathrm{ml}$ had significantly higher mean values compared to the control. AMs exposed to CF 20 and $25 \mu \mathrm{g} / \mathrm{ml}$ had significantly higher mean values compared to the respective control. The concentration of LDH in the supernatant of RAW 264.7 cells exposed to PT or SiC are shown in Fig. 7. Significantly higher mean values were observed in the PT 20, 40 and $60 \mu \mathrm{g} / \mathrm{ml}$ groups, and the $\mathrm{SiC}$ 20,40 and $60 \mu \mathrm{g} / \mathrm{ml}$ groups compared to the respective control.

\section{Morphological observation}

Immunofluorescent micrographs of the cells stained with FITC anti- $\alpha$ tubline are shown in Fig. $8 \mathrm{a}-\mathrm{d}$ for the PBS, $\mathrm{CF}, \mathrm{PT}$ and SiC groups, respectively. The fine network of 


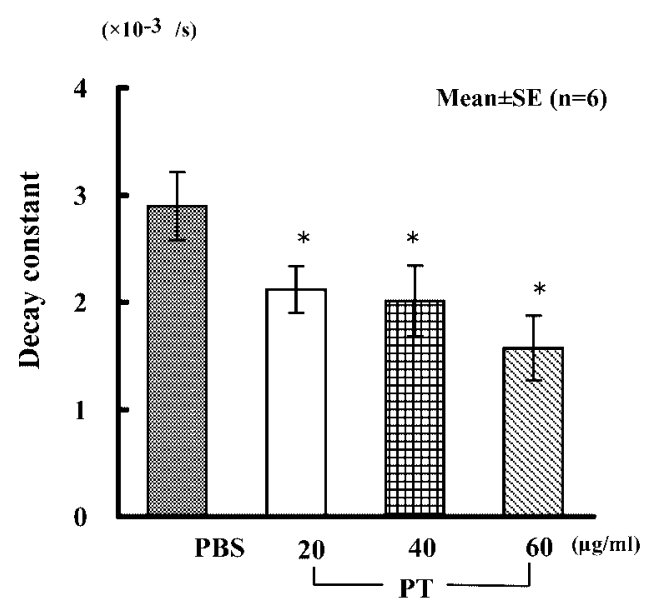

a PT

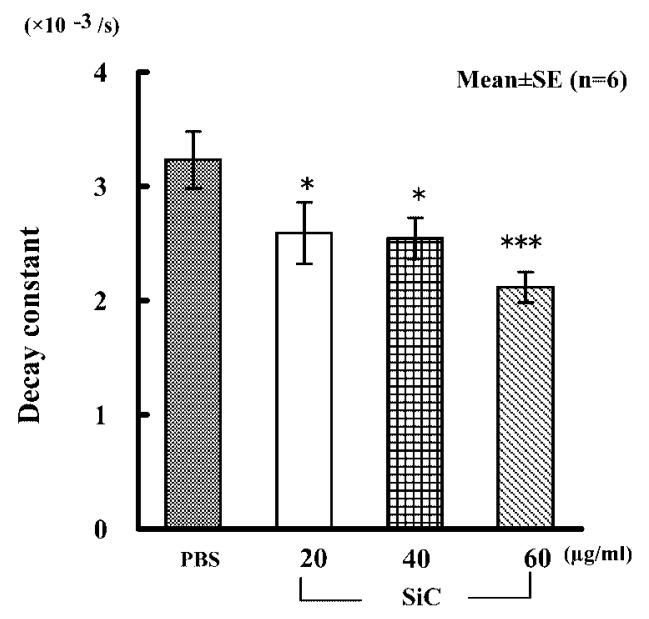

b $\mathrm{SiC}$

Fig. 5. The decay constant of RAW 264.7 cells exposed to PT or SiC after magnetization.

Each bar represents mean value, and error bars represent SE $(n=6)$. The mean values of decay constants $(\lambda)$ were compared among the groups $(* p<0.05, * * * p<0.001$; compared with the PBS groups).

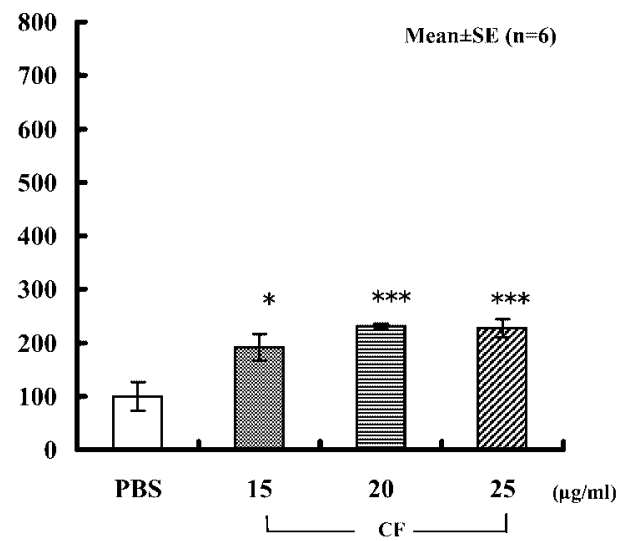

a RAW 264.7 cells

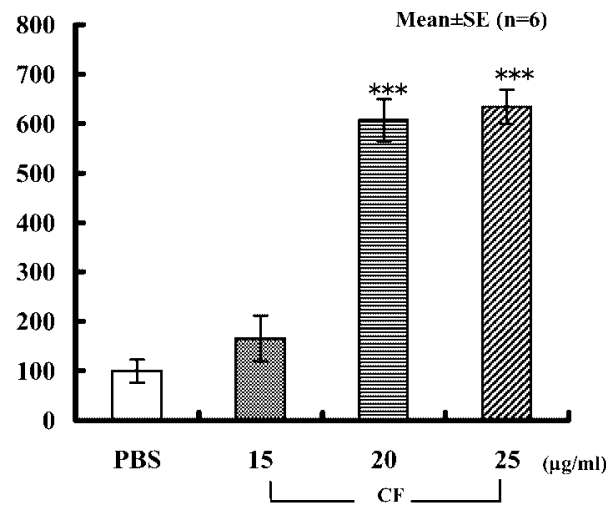

b AMs

Fig. 6. The mean value of LDH in the supernatant of RAW 264.7 cells and alveolar macrophage (AM) exposed to $\mathbf{C F}$.

Bars represent mean values and error bars represent $\mathrm{SE}(\mathrm{n}=6)$. LDH mean values were compared among the groups $(* p<0.05, * * * p<0.001$; compared with the PBS groups).

microtubules and the spherical shape or the cells were clearly seen in the PBS groups. In the CF group, the englobed fibers were found in the cytoplasm. The aggregation of microtubules was seen, and the spherical shape of the cells became unclear. In the PT groups, the aggregation of microtubules was seen while the spherical shape of the cell was also unclear. The englobed fibers were also found in the cytoplasm. In the $\mathrm{SiC}$ groups, the aggregation of microtubules was partly observed in the cells that englobed fibers. While the spherical shape of the cells was relatively clear compared with the CF or PT- exposed cells. SEM images of the RAW 264.7 cells are shown in Fig. 9a-d for the PBS, CF, PT and SiC groups, respectively. In the PBS group, the cell was spherical, and many microvilli were observed on the surface. In the CF groups, the spherical shape of the cell was lost, the microvilli on the surface disappeared, and many fibers twined around and englobed the cells. Likewise, in the PT and SiC groups, fibers tangled around and englobed the cells. The depletion of microvilli from the surface of the cells was also observed. TEM images of the RAW 264.7 cell are shown in Fig. 10a-d of the PBS, $\mathrm{CF}, \mathrm{PT}$ and $\mathrm{SiC}$ groups, respectively. 


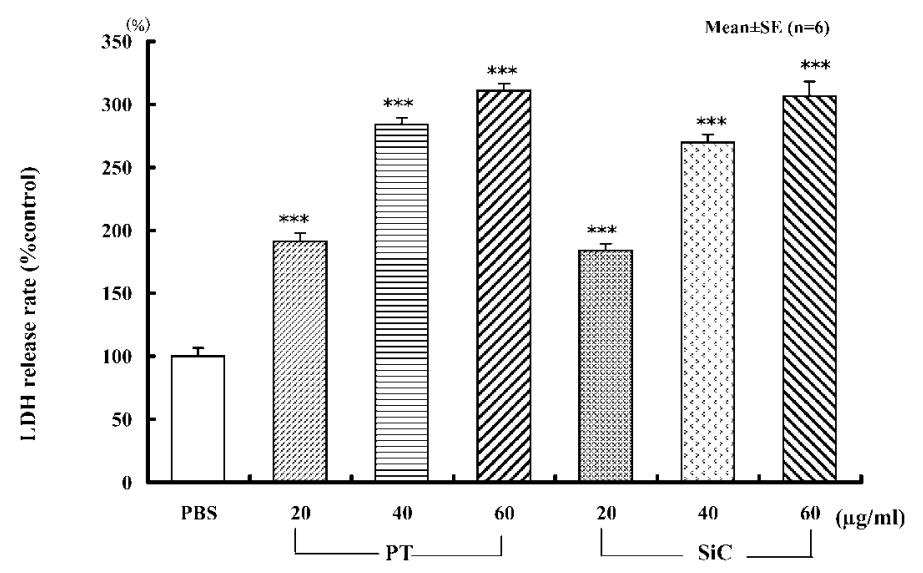

Fig. 7. The mean value of LDH in the supernatant of RAW 264.7 cells exposed to PT or SiC.

Bars represent mean values and error bars represent SE $(n=6)$. LDH mean values were compared among the groups $(* * * p<0.001$; compared with the PBS group).
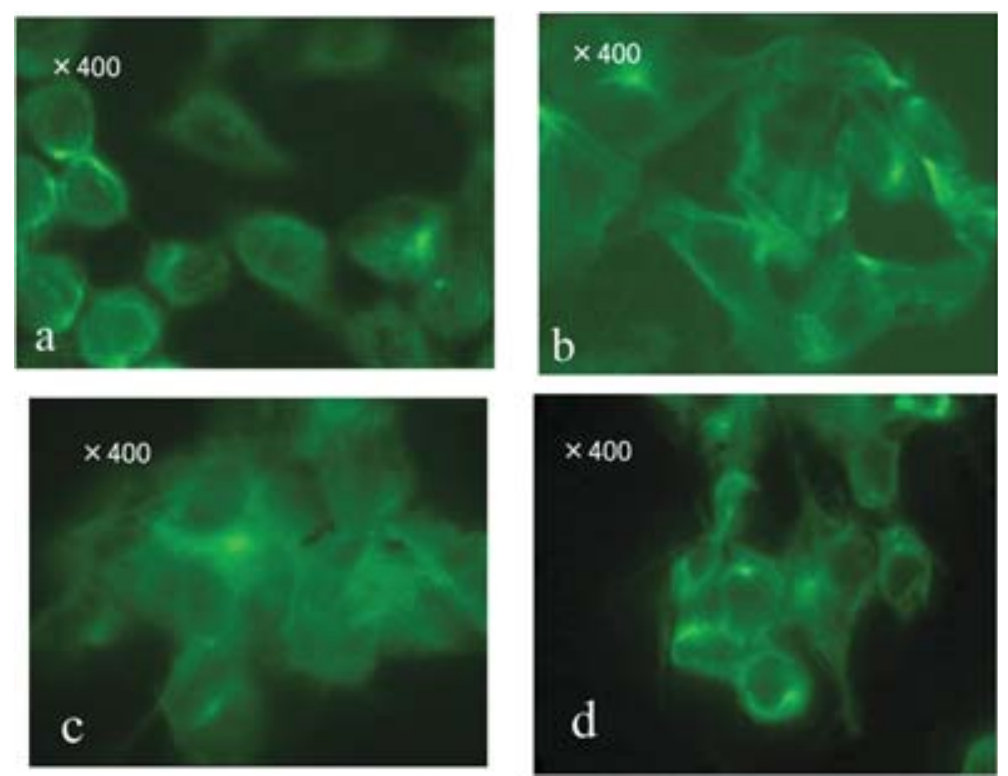

Fig. 8. Immunofluorescent micrographs of RAW 264.7 cells exposed to CF, PT or $\mathrm{SiC}$.

Cells stained with $\alpha$-tubulin FITC conjugate (Sigma-Aldrich, Tokyo) by the antibody method $\times 400$. a. A fine network of microtubules was observed in the PBS group. b. An aggregation of microtubules was observed in the CF $20 \mu \mathrm{g} / \mathrm{ml}$ group. c. An aggregation of microtubules were observed while the spherical shape of the cells were unclear in the PT $60 \mu \mathrm{g} / \mathrm{ml}$ group. d. An aggregation of microtubules was partly observed in the cells which englobed fibers in the $\mathrm{SiC} 60 \mu \mathrm{g} / \mathrm{ml}$ group.

In the PBS group, a horseshoe-shaped nucleus, phagocytic vacuoles and lysosomes were observed. In the $\mathrm{CF}$ group, many vacuoles were observed, and a few fibers were englobed in the cytoplasm. In the PT group, many vacuoles also were observed, and many fibers were englobed in the cytoplasm.
$\mathrm{SiC}$, being an extremely hard material, made it difficult to slice samples. The micrograph was relatively unclear, however, a few fibers and many vacuoles in the cytoplasm could be observed. 

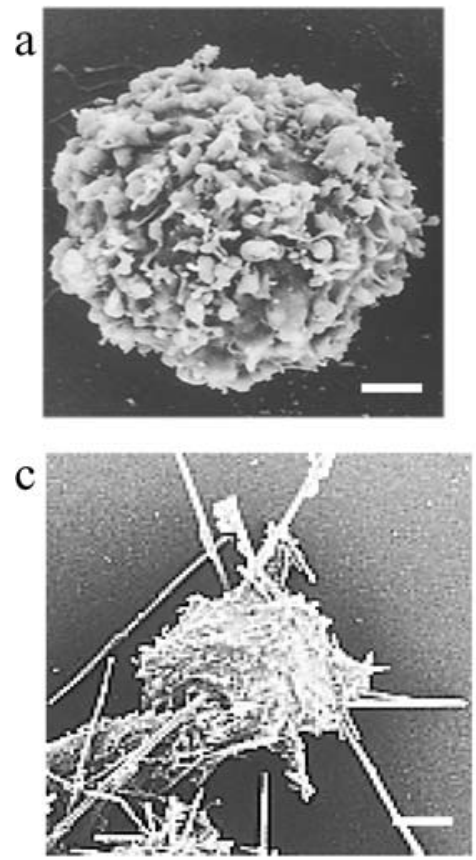

b

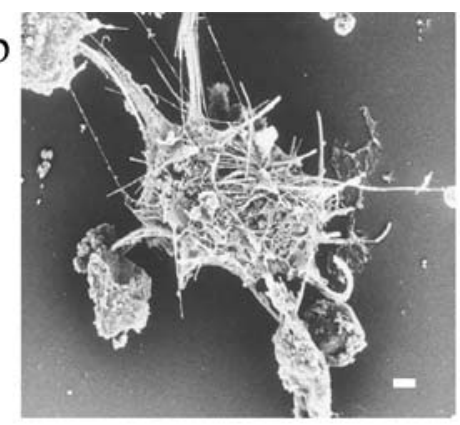

d

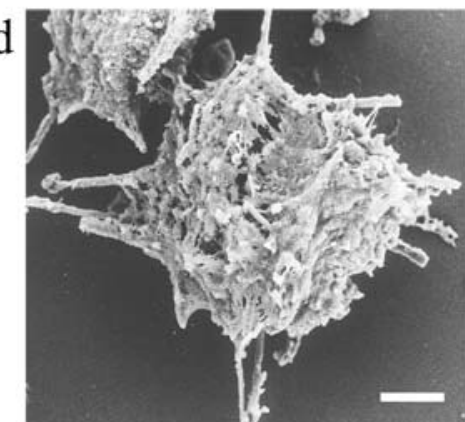

Fig. 9. Scanning electron micrograph of RAW 264.7 cells exposed to CF, PT or SiC.

RAW 264.7 cells exposed to PBS, CF $20 \mu \mathrm{g} / \mathrm{ml}$, PT $60 \mu \mathrm{g} / \mathrm{ml}$, SiC $60 \mu \mathrm{g} / \mathrm{ml}$ were incubated at $37^{\circ} \mathrm{C}$ in $5 \% \mathrm{CO}_{2}$ for $48 \mathrm{~h}$. Bar=1 $\mu \mathrm{m}$. a. RAW 264.7 cells exposed to PBS, a large number of microvilli on the surface of ball-shaped cells were observed. b. Exposed to $\mathrm{CF} 20 \mu \mathrm{g} / \mathrm{ml}$, many fibers that had twined around the cells were visible. c. Exposed to PT $60 \mu \mathrm{g} / \mathrm{ml}$, show that many fibers pierce the cells. d. In cells exposed to $\mathrm{SiC} 60 \mu \mathrm{g} / \mathrm{m}$, many fibers were seen piercing the cells from various directions.

\section{Discussion}

Cell magnetometry using AMs is a useful method for screening the toxic effects of fibrous materials ${ }^{9-13}$. Magnetic particles of $\mathrm{Fe}_{3} \mathrm{O}_{4}$ are englobed by macrophages obtained from bronchoalveolar lavage, and the cells are magnetized externally. The RMF, generated from magnetized $\mathrm{Fe}_{3} \mathrm{O}_{4}$ in cells, is measured right after external magnetization. The rapid reduction of RMF is called relaxation. Unidirectional particles are unified by external magnetization. However, after the cessation of magnetization, these particles rotate randomly due to phagocytic movement of the cytoskeleton ${ }^{18)}$, the orderly arranged alignment of magnetic particles is disturbed according to time, and as a result, RMF is attenuated. The cytoskeleton is mainly composed of microtubules, microfilaments and intermediate filaments, and plays an important role in the maintenance of the structure of the cytoplasm, intracellular transport ${ }^{19,20)}$. Delayed relaxation observed in association with exposure to toxic substances would be attributable to physical and chemical properties of toxic substances ${ }^{18,21)}$.
The murine cell line RAW 264.7 is lately being used as an in vitro model of alveolar macrophage. If RAW 264.7 cells can be used in cell magnetometry, it would be possible to evaluate the toxicities of fibrous materials without the limitations of animal experiments. To examine the usefulness of RAW 264.7 cells in cell magnetometry, we compared RAW 264.7 cells and AMs exposed to CF with cell magnetometry.

In cell magnetometry in RAW 264.7 cells and AMs, rapid relaxation was observed in the PBS groups on the experimental protocol in this study. In RAW 264.7 cells, the groups exposed to $\mathrm{CF} 15,20$ and $25 \mu \mathrm{g} / \mathrm{ml}$ demonstrated significantly delayed relaxation compared to that in the respective PBS groups. In AMs, the groups exposed to CF 20 and $25 \mu \mathrm{g} / \mathrm{ml}$ demonstrated significantly delayed relaxation compared to that in the respective PBS groups. The mean decay constants of RAW 264.7 cells exposed to CF 15,20 and $25 \mu \mathrm{g} / \mathrm{ml}$ were significantly lower compared to those in the PBS groups. In AMs, the groups exposed to CF 20 and $25 \mu \mathrm{g} / \mathrm{ml}$ were significantly lower means compared to those in the respective PBS groups. RAW 264.7 
a

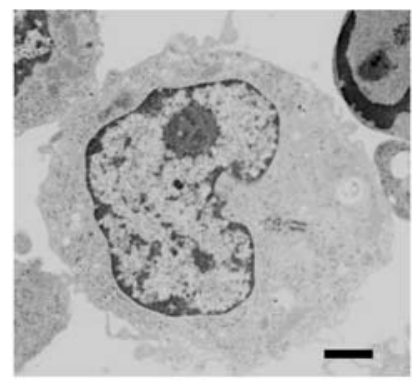

c

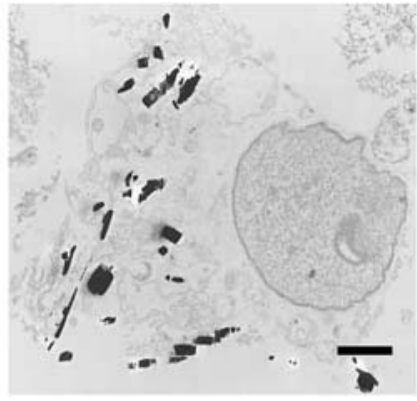

b
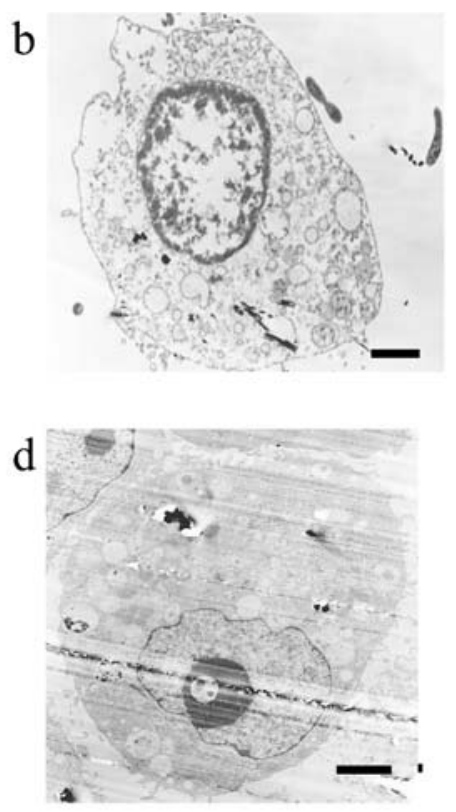

Fig. 10. Transmission electron micrographs of RAW 264.7 cells exposed to CF, PT or SiC.

RAW 264.7 cells exposed to PBS or CF $20 \mu \mathrm{g} / \mathrm{ml}$ or PT $60 \mu \mathrm{g} / \mathrm{ml}$ or SiC $60 \mu \mathrm{g} /$ $\mathrm{ml}$ were incubated at $37^{\circ} \mathrm{C}$ in $5 \% \mathrm{CO}_{2}$ for $48 \mathrm{~h}$. Bar=1 $\mu \mathrm{m}$. a. RAW 264.7 cells exposed to PBS. The shape of the cell appears round. b. In the cell exposed to CF $20 \mu \mathrm{g} / \mathrm{ml}$, many vacuoles were visible, and a few fibers were observed in the cytoplasm. c. Cells exposed to PT $60 \mu \mathrm{g} / \mathrm{ml}$ show many vacuoles and fibers englobed in the cytoplasm. d. The cells exposed to $\mathrm{SiC} 60 \mu \mathrm{g} / \mathrm{ml}$ show many vacuoles, and a few fibers were visible in the cytoplasm.

cells proved more sensitive than AMs to detect the difference in cell magnetometry. These results suggest that it is adequate to use RAW 264.7 cells in cell magnetometry. For the LDH level in the supernatant, the RAW 264.7 cells exposed to 15 $\mu \mathrm{g} / \mathrm{ml}$ of CF and the AMs exposed to $20 \mu \mathrm{g} / \mathrm{ml}$ of CF had significantly higher mean values compared to their respective controls. These results were related with those of the cell magnetometry. Compared to the levels that induce significant difference in cell magnetometry and LDH in RAW 264.7 cells, the $15 \mu \mathrm{g} / \mathrm{ml}$ of CF groups had significantly higher mean values compared to the control in both cell magnetometry and LDH. Therefore, it is suggested that cell magnetometry and LDH can be good indicators of cytotoxicity of fibers at the same level.

On the basis of these results, the toxic effects of PT or $\mathrm{SiC}$ were evaluated by cell magnetometry and LDH assay. RAW 264.7 cells exposed to PT 20, 40 and $60 \mu \mathrm{g} / \mathrm{ml}$ and exposed to $\mathrm{SiC} 20,40$ and $60 \mu \mathrm{g} / \mathrm{ml}$ demonstrated significantly delayed relaxations compared to those in the respective PBS groups. The mean values of $\mathrm{B}_{20}(\%)$ were higher in the groups exposed to PT and $\mathrm{SiC}$ in a dose- dependent manner. The mean values of decay constants of the groups exposed to $\mathrm{SiC}$ and PT were smaller as the concentrations increased. The decay constants of the PT $20,40,60, \mathrm{SiC} 20,40$ and $60 \mu \mathrm{g} / \mathrm{ml}$ groups were significantly lower compared with those of the respective PBS groups. These results from the mean value of $\mathrm{B}_{20}(\%)$ and the decay constants suggested that the exposure to MMMFs as well as the exposed to CF impaired the function of RAW 264.7 cells. The level of LDH in the supernatant of RAW 264.7 cells exposed to PT or SiC increased in a dose-dependent manner. The significantly higher values were observed in the PT 20, 40 and $60 \mu \mathrm{g} / \mathrm{ml}$ groups, and the $\mathrm{SiC} 20,40$ and $60 \mu \mathrm{g} / \mathrm{ml}$ groups.

In exposed PT groups, the results of LDH levels were the same as those in AMs in a previous study ${ }^{11)}$. In exposed $\mathrm{SiC}$ groups, the results of $\mathrm{LDH}$ levels were related the cell magnetometry measurement. In previous studies, there were no significant increases in LDH levels in the supernatant of $\mathrm{AMs}$ exposed to $\mathrm{SiC}$ groups ${ }^{10)}$. In present study, $\mathrm{LDH}$ measurement may be sensitive to detect the toxic effect of PT and SiC. PT and SiC fibers are relatively long and the 
number of PT and SiC fibers per gram is lager than that of CF fibers ${ }^{24)}$. This may be a factor in the strong impairment of the cell membranes of RAW 264.7 cells.

In a previous study ${ }^{25}$, the RAW 264.7 cells exposed to PT or SiC at $100 \mu \mathrm{g} / \mathrm{ml}$ had a significantly higher level of LDH compared with the control. In addition, the increase in LDH was similar to cells exposed to crocidolite. Increases in LDH in the supernatants of RAW 264.7 cells exposed to high concentrations of PT or SiC were confirmed in this study at relatively lower levels. In inhalation studies of PT and $\mathrm{SiC}$ in rats, pulmonary fibrosis ${ }^{26)}$, and mesotheliomas and pulmonary fibrosis ${ }^{27)}$ were observed, respectively. This suggested the possible injurious nature of PT and SiC to the lungs. The impairment of macrophages by PT or SiC suggested in the present study could be a mechanism of lung injury induced by $\mathrm{PT}$ or $\mathrm{SiC}$ in vivo.

To examine actual phagocytosis and cytoskeletal changes, we conducted morphological observations using the electron micrograph and fluorescent antibody method ( $\alpha$-tubulin FITC conjugate). From the results of TEM, the cells actually phagocytosed CF, PT and SiC fibers. The increase in the number of vacuoles in the cytoplasm of the cells that englobed $\mathrm{CF}, \mathrm{PT}$ and SiC fibers were related the observations of AMs by TEM in previous studies ${ }^{10,11,22)}$. Phagocytosis of fibers was also confirmed in SEM observations. Decrease in the number of microvilli or the surface of the cells that englobed $\mathrm{CF}, \mathrm{PT}$ and $\mathrm{SiC}$ fibers also were related the observations of AMs by SEM in those studies. In morphological observations using immunofluorescent staining in the cells exposed to levels that showed significant increase in $\mathrm{B}_{20}(\%)$, aggregation of microtubules was observed in the cell-englobed fibers. Microtubles, one of the components of the cytoskeleton, are related to rotational movement of phagosomes. From observations using immunofluorescent staining, impairment of the cytoskeleton was suggested in the cells that exhibited delayed relaxation.

In conclusion, these results of MMMFs suggest that cell magnetometry using RAW 264.7 cells is useful for the evaluation of toxic effects. The combined use of both LDH and cell magnetometry may be the most efficacious way to evaluate MMMFs.

\section{Acknowledgements}

The authors are grateful to Ms Y. Sugiura, Ms Y. Komatsu, Ms Y. Inoue and Ms M. Koyama of the Department of Preventive Medicine and Public Health, and Mr S. Miyazawa and Ms T. Nemoto of the Electron Microscope Center, Kitasato University School of Medicine, for their advice and expertise. This study was supported by the Grants-inAid for Scientific Research from the Japanese Ministry of Education, Culture, Sports, Science and Technology. We also thank Mr Robert E. Brandt for editing the manuscript.

\section{References}

1) Mossman BT, Bignon J, Corn M, Seaton A, Gee JB (1990) Asbestos: scientific developments and implications for public policy. Science 19, 247, 294-301.

2) Churg A, Wright JL, Vedal S (1993) Fiber burden and patterns of asbestos-related disease in chrysotile miners and millers. Am Rev Respir Dis 148, 25-31.

3) Lee KP, Barras CE, Griffith FD, Waritz RS (1979) Pulmonary response to glass fiber by inhalation exposure. Lab Invest 40, 123-33.

4) Tilkes F, Beck EG (1983) Macrophage functions after exposure to mineral fibers. Environ Health Perspect 51, 6772.

5) Stanton MF, Layard M, Tegeris A, Miller E, May M, Morgan E, Smith A (1981) Relation of particle dimension to carcinogenicity in amphibole and asbestoses and other fibrous minerals. J Natl Cancer Inst 67, 965-75.

6) Sibille Y, Reynolds HY (1990) Macrophages and polymorphonuclear neutrophils in lung defense and injury. Am Rev Respir Dis 141, 471-501.

7) Blake T, Castranova V, Schwegler-Berry D, Baron P, Deye GJ, Li C, Jones W (1998) Effect of fiber length on glass microfiber cytotoxicity. J Toxico Environ Health 54, 243 59.

8) Fujino A, Hori H, Higashi T, Morimoto Y, Tanaka I, Kaji H (1995) In-vitro biological study to evaluate the toxic potentials of fibrous materials. Int J Occup Environ Health 1, 21-8.

9) Keira T, Karube H, Aizawa Y, Niitsuya M, Shinohara S, Kuwashima A, Mashimo K, Kotani M (1996) Effect of limestone on the alveolar macrophages of hamsters. Jpn J Traumatol Occup Med 44, 313-8 (in Japanese with English abstract).

10) Watanabe M, Okada M, Aizawa $Y$, Sakai Y, Yamashina S, Kotani M (2000) Magnetometric evaluation for the effects of silicon carbide whiskers on alveolar macrophages. Ind Health 38, 239-45.

11) Watanabe M, Shibata K, Okada M, Kudo Y, Niitsuya M, Satoh T, Kotani M, Aizawa Y (2002) Magnetometric evaluation for cytotoxicity of potassium octatitanate whisker on alveolar macrophages of Fischer 344 rats. J Occup Health 44, 321-8.

12) Kudo $Y$, Watanabe M, Okada M, Shinji H, Niitsuya M, Satoh T, Sakai Y, Kohyama N, Kotani M, Aizawa Y (2003) Comparative cytotoxicity study of rock wool and chrysotile by cell magnetometric evaluation. Inhal Toxicol 15, 127595.

13) Shinji H, Watanabe M, Kudo Y, Niitsuya M, Tsunoda M, Satoh T, Sakai Y, Kotani M, Aizawa Y (2005) The cytotoxicity 
of microglass fibers on alveolar macrophages of Fischer 344 rats evaluated by cell magnetometry, cytochemistry and morphology. Environ Health Prevent Med 10, 111-9.

14) Ye J, Shi X, Jones W, Rojanasakul Y, Cheng N, SchweqlerBerry D, Baron P, Deye GJ, Li C, Castranova V (1999) Critical role of glass fiber length in TNF-alpha production and transcription factor activation in macrophages. Am J Physiol 276, 426-34.

15) Gozal E, Ortiz LA, Zou X, Burow ME, Lasky JA, Friedman M (2002) Silica-induced apoptosis in murine macrophage: involvement of tumor necrosis factor-alpha and nuclear factorkappaB activation. Am J Respir Cell Mol Biol 27, 91-8.

16) Nishiike T, Nishimura $Y$, Wada Y, Iguchi H (2005) Production of nitric oxide elevates nitrosothiol formation resulting in decreased glutathione in macrophages exposed to asbestos or asbestos substitutes. Arch Toxicol 79, 83-9.

17) Kohyama N, Tanaka I, Tomita M, Kudo M, Shinohara $Y$ (1997) Preparation and characteristics of standard reference samples of fibrous minerals for biological experiments. Ind Health 35, 415-32.

18) Brain JD, Bloom SB, Valberg PA (1988) Magnetometry: a tool for studying the cell biology of macrophages. In: Biomagnetism '87, Tokyo, Atsumi K, Kotani M, Ueno S, Katila T, Williamson SJ (Eds.), 10-7, Tokyo Denki University Press, Tokyo.

19) Cassimeris L (1993) Regulation of microtubule dynamic instability. Cell Motil Cytoskeleton 26, 275-81.

20) Maccioni RB, Combiazo V (1995) Role of microtubule- associated proteins in the control of microtubule assembly. Physiol Rev 75, 835-64.

21) Nemoto I, Ogura K, Toyotama H (1989) Estimation of the energy of cytoplasmic movements by magnetometry: effects of temperature and intracellular concentration of ATP. IEEE Trans Biomed Eng 36, 598-607.

22) Keira T, Okada M, Katagiri H, Aizawa Y, Okayasu I, Kotani M (1998) Magnetometric evaluation for the effect of chrysotile on alveolar macrophages. Tohoku J Exp Med 186, 87-98.

23) Okada M, Karube H, Niitsuya M, Aizawa Y, Okayasu I, Kotani M (1999) In vitro toxicity of gallium arsenide in alveolar macrophages evaluated by magnetometry, cytochemistry and morphology. Tohoku J Exp Med 189, 267-81.

24) Yamato H, Morimoto Y, Tsuda T, Ohgami A, Kohyama N, Tanaka I (1998) Fiber number per unit weight of JFM standard reference samples determined with a scanning electron microscope. Ind Health 36, 384-7.

25) Ishihara Y, Koyama N, Nagai A, Kagawa J (1998) Cellular biological effects and a single transtracheal injection test in three types of whisker fibers. Inhal Toxicol 10, 275-91.

26) Lee KP, Barras CE, Griffith FD, Waritz RS, Lapin CA (1981) Comparative pulmonary responses to inhaled inorganic fibers with asbestos and fiberglass. Environ Res 24, 167-91.

27) Davis JMG, Brown DM, Cullen RT, Donaldson K, Jones AD, Miller BG, McIntosh C, Searl A (1996) A comparison of methods of determining and predicting the pathogenicity of mineral fibers. Inhal Toxicol 8, 747-70. 